\title{
Effect of Deposit Au Thin Layer Between Layers of Perovskite Solar Cell on Cell's Performance
}

\author{
Ahmed A. Assi ${ }^{1 a^{*}}$, Wasan R. Saleh ${ }^{2 b}$, and Ezeddin Mohajerani ${ }^{3 c}$ \\ ${ }^{1,2}$ Department of Physics, College of Science, University of Baghdad, Baghdad, Iraq \\ ${ }^{3}$ Laser and Plasma Research Institute, Shahid Beheshti University, Tehran, Iran \\ bE-mail: wasan_alazawi@yahoo.com, ${ }^{c}$ E-mail: e-mohajerani@sbu.ac.ir \\ a*Corresponding author: ahma.ali.asi@gmail.com
}

\begin{abstract}
The present work aims to fabricate $\mathrm{n}$-i-p forward perovskite solar cell (PSC) with structure (FTO/compact $\mathrm{TiO}_{2} /$ compact $\mathrm{TiO}_{2} / \mathrm{MAPbI}_{3}$ Perovskite/ hole transport layer/ Au). P3HT, CuI and Spiro-OMeTAD were used as hole transport layers. A nano film of $25 \mathrm{~nm}$ gold layer was deposited once between the perovskite (PSK) layer and the electron transport layer (ETL), then between hole transport layer (HTL) and the perovskite layer. The performance of the forwardperovskite solar cell was studied. The role of the electron transport layer and the hole transport layer in the perovskite solar cell was presented. The structural, morphological and electrical properties were studied with X-ray diffractometer (XRD), field emission scanning electron microscope (FE-SEM) and current-voltage (J-V) characteristic curves, respectively. J-V curves revealed that the deposition of the Au layer between the perovskite layer and electron transport layer reduced the power conversion efficiency from $3 \%$ to $0.08 \%$ when one layer of $\mathrm{C}$. $\mathrm{TiO}_{2}$ is deposited in the PSC and to $0.11 \%$ with two layers of $\mathrm{C}$. $\mathrm{TiO}_{2}$. Power conversion efficiency, with $\mathrm{CuI}$ as the hole transport layer, showed an increase from $0.5 \%$ to $2.7 \%$ when $\mathrm{Au}$ layer was deposited between PSK and CuI layers. Also, $\mathrm{I}_{\mathrm{sc}}$ increased from $6.8 \mathrm{~mA}$ to $17.4 \mathrm{~mA}$ and $\mathrm{V}_{\mathrm{oc}}$ from $0.3 \mathrm{~V}$ to $0.5 \mathrm{~V}$. With depositing Au layer between P3HT and PSK layers, the results showed an increase in the efficiency from $1 \%$ to $2.6 \%$ and an increase in $\mathrm{I}_{\mathrm{sc}}$ from $10.7 \mathrm{~mA}$ to $30.5 \mathrm{~mA}$, while $\mathrm{V}_{\mathrm{oc}}$ decreased from $0.75 \mathrm{~V}$ to $0.5 \mathrm{~V}$.
\end{abstract}

Article Info.

Keywords:

perovskite solar cell, gold layer, CuI, P3HT, compact $\mathrm{TiO}_{2}$

\section{Article history:}

Received: Aug. 10, 2021

Accepted: Oct. 04, 2021

Published: Dec. 01, 2021

\section{Introduction}

The last few years have seen an explosion of interest in photo-voltaic (PV) systems with an organic-inorganic lead halide perovskite active layer, that appeals to the technical community according to their high efficiency and inexpensive cost [1-3]. PV devices based on perovskite materials have demonstrated monotonic increase in power conversion efficiency (PCE) [4], rising from 3.9\% when using $\mathrm{CH}_{3} \mathrm{NH}_{3} \mathrm{PbBr}_{3}$ and $\mathrm{CH}_{3} \mathrm{NH}_{3} \mathrm{PbI}_{3}$ as light absorbers in DSSCs with an iodine-based liquid electrolyte to over $20 \%$ [5, 6], with the current world record of 25.5 percent certified in 2021 by the National Renewable Energy Laboratory in the USA (NREL) [7].

The Perovskite Solar Cell (PSC) is consisted of five layers: hole transport layer (HTL), metal-based cathode, electron transport layer, perovskite as the absorber layer, and transparent conductive oxide (TCO) [8]. The transport layers are critical in determining a PSC performance. The hole transport layer (HTL) collects holes from the absorber layer and transports them to the cathode, where they are blocked by electrons. 
To operate as a HTL, any substance must have a higher occupied molecular orbital (HOMO) than the perovskite absorber layer. Numerous hole transport layers (HTLs) have been employed, including PTAA, Spiro-OmeTAD, $\mathrm{CuO}, \mathrm{Cu}_{2} \mathrm{O}, \mathrm{Cui}$, and $\mathrm{NiO}$ [9]. While, the electron transport layer (ETL) collects electrons from the absorber layer and transports them to the anode, where they are blocked by holes. To be an ETL, a material's lowest unoccupied molecular orbital (LUMO) levels must be lower than those of the perovskite absorber layer. The ETL should have a high transparency in the UV-Visible range in order for all photons to passing through and then absorbed maximally by the absorber layer. Various ETLs are employed, including $\mathrm{SiO}_{2}, \mathrm{SnO}_{2}, \mathrm{TiO}_{2}$, and $\mathrm{ZnO}$ [9].

The arrangement of the device is critical when assessing the overall performance of (PSCs). PSCs can further be classified into p-i-n (inverted) and n-i-p (regular or forward) structures based on the transport (electron/hole) material present on the outer portion of the cell/encountered by incident light [10]. For n-i-p structures, the conventional device structure of PSCs includes a transparent conducting electrode (Fluorine-doped tin oxide (FTO) or Indium tin oxide (ITO), an ETL, a perovskite (PSK) active layer, and a $\mathrm{HTL}$. $\mathrm{TiO}_{2}, \mathrm{SnO}_{2}$, and $\mathrm{ZnO}$ are the most often utilized ETL materials, whereas Spiro-OMeTAD or the more stable Poly[bis(4-phenyl) (2,4,6-trimethylphenyl) amine is employed for the hole transport layer (PTAA) [11].

The fill factor (FF) usually used to quantify solar cell defects. It is defined as the ratio of the dark blue (maximum power output) to the light blue rectangles $\left(V_{O C} J_{S C}\right)$, as appear in Fig. (1), and can be calculated as [12]:

$$
\mathrm{FF}=\frac{\mathrm{V}_{\text {MPP.JMMP }}}{\mathrm{V}_{\text {OC.JSC }}}=\frac{\mathrm{P}_{\text {MPP }}}{\mathrm{V}_{\text {OC.JSC }}}<1
$$

where $\mathrm{V}_{\text {MPP }}$ is the voltage at maximum power output point, $\mathrm{J}_{\text {MPP }}$ is the current at maximum power output point, $\mathrm{J}_{\mathrm{sc}}$ is the short-circuit current density, $\mathrm{V}_{\mathrm{oc}}$ is the opencircuit voltage, and $\mathrm{P}_{\mathrm{MPP}}$ is the maximum power output point.

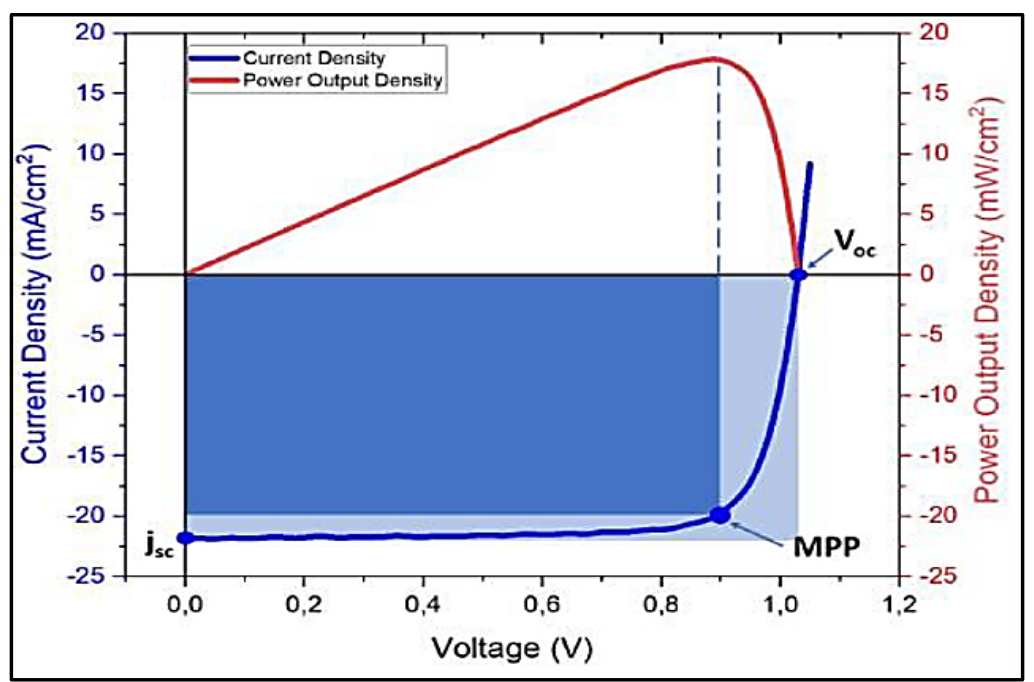

Figure 1: A solar cell's typical current density-voltage curve and matching electrical power output density. The current density $(J)$ of the short-circuit, voltage $\left(V_{o c}\right)$ of the open-circuit, and maximum power output point at (PMPP) are all denoted [13].

The most critical aspect of a solar system is its (PCE), which is defined as the ratio of the generated to the incident power and is computed using the following equation [12]:

$$
\mathrm{PCE}=\frac{\mathrm{P}_{\mathrm{MPP}}}{\mathrm{P}_{\text {incident }}}=\frac{\mathrm{FF} \cdot \mathrm{V}_{\mathrm{OC}} \cdot \mathrm{ISC}_{\mathrm{SC}}}{\emptyset_{\mathrm{E}}^{\mathrm{AM} 1.5 \mathrm{G}} \cdot \mathrm{A}}
$$


where $\Phi_{\mathrm{E}}{ }^{\mathrm{AM} 1.5 \mathrm{G}}$ is the power density of the sun on the Earth's surface, and $\mathrm{A}$ is the area of a solar cell.

This work is aimed to study the effect of gold nano-film on the performance of PCS when it is placed between perovskite layer and each of the electron and hole transport layers. Also, it demonstrates the importance of the hole transport layer and the electron transport layer in the cell when they are separated from the perovskite layer by a thin separator layer.

\section{Experimental work}

\subsection{Chemical Materials}

The used materials were fluorine doped tin oxide coated glass (FTO-glass), lead iodide $\left(\mathrm{PbI}_{2}\right)$, and methylamine iodide (MAI), which are from Sharifsolar Company. The titanium tetraisopropoxide (TTIP), ethanol, Hydrochloric acid $(\mathrm{HCl})$, dimethyl sulfoxide (DMSO), dimethylformamide (DMF), chlorobenzene (CB), Lithium bis (trifluoromethanesulfonyl) imide (LITESI), acetonitrile, and Copper(I) iodide (CuI) are from Merck company. The Spiro- OMeTAD, Poly(3-hexylthiophene-2,5-diyl) (P3HT) are from Ossila company, and 4-tert-Butylpyridine, and 24 karat alloy gold (Au).

\subsection{Preparation of solar cells layers}

There are many steps to prepare perovskite solar cell layers. In this work, the method used was the same method used by A.A. Assi et al. [14, 15]. The conductive glass FTO/glass substrates were patterned by laser etching and sequentially washed with deionized water, detergent, acetone and isopropanol. Afterwards, the substrates were dried with nitrogen gas then left overnight in the oven at $60{ }^{\circ} \mathrm{C}$ to keep them dry and clean.

For the synthesis of C.TiO 2 layer two solutions were prepared: The first solution was prepared by adding $365 \mu$ l titanium tetraisopropoxide (TTIP) to $2530 \mu$ l ethanol with stirring for one hr. at room temperature. The second solution was a mixture of $35 \mu \mathrm{l}$ of Hydrochloric acid $(\mathrm{HCl})$ and $2530 \mu \mathrm{l}$ of ethanol. After $1 \mathrm{~h}$, the second solution was slowly added to the first. The mixture was deposited on a clean FTO glass using spin coating in two steps: beginning first with a speed of $1500 \mathrm{rpm}$ for $15 \mathrm{~s}$ and then with a speed of 4000 $\mathrm{rpm}$ for $25 \mathrm{~s}$ with acceleration $12 \mathrm{R}$-Time, then dried at a temperature of $140^{\circ} \mathrm{C}$ for 10 min. The thickness of each layer was approximately $(200-250) \mathrm{nm}$. The second layer was added using spin coating (4000 rpm, the 30s, $12 \mathrm{R}$-Time) and then annealed at a temperature of $500^{\circ} \mathrm{C}$ for $30 \mathrm{~min}$.

The perovskite layer was prepared by mixing $461 \mathrm{mg}$ of lead iodide $\left(\mathrm{PbI}_{2}\right)$ with 159 $\mathrm{mg}$ of methylamine iodide (MAI) and dissolved in a solvent containing $78 \mathrm{mg}$ of dimethyl sulfoxide (DMSO) and $600 \mathrm{mg}$ of dimethylformamide (DMF). The mixture was stirred for $10 \mathrm{~min}$ at $100{ }^{\circ} \mathrm{C}$ then for extra $20 \mathrm{~min}$. at room temperature. Spin coating was used for the deposition of the PSK layer in three steps: $(2000 \mathrm{rpm})$ for $10 \mathrm{~s},(4000 \mathrm{rpm})$ for 10 $\mathrm{s}$ and the last step at $2000 \mathrm{rpm}$ for $10 \mathrm{~s}$ with dropwise adding of $200 \mu \mathrm{l}$ of chlorobenzene (CB) as anti-solvent.

For hole transport layer, Spiro- OMeTAD was used, which was prepared using two solutions: The first solution, called S1, was prepared by mixing $72 \mathrm{mg}$ of Spiro with $1 \mathrm{ml}$ of CB and stirred for $1 \mathrm{~h}$ with a stirrer. The second solution, called S2, consist of $520 \mathrm{mg}$ of Lithium bis(trifluoromethanesulfonyl)imide (LITESI) mixed with $1 \mathrm{ml}$ of acetonitrile and stirred for $1 \mathrm{~h}$ with a stirrer. S1 was mixed with $17.5 \mathrm{ml}$ of S2 and $28.8 \mu 1$ of 4-tertButylpyridine and stirred for $20 \mathrm{~min}$ with a stirrer. The final mixture was filtered by 0.22 $\mu \mathrm{m}$ filter paper. The final solution was deposited using spin coating technique at 4000 rpm for the 20 s. 
Gold $(\mathrm{Au})$ was deposited with a thickness between $70-100 \mathrm{~nm}$ as a cathode electrode using the thermal evaporation method. A hot plate at temperature $80{ }^{\circ} \mathrm{C}$ was used to remove the excess solvent.

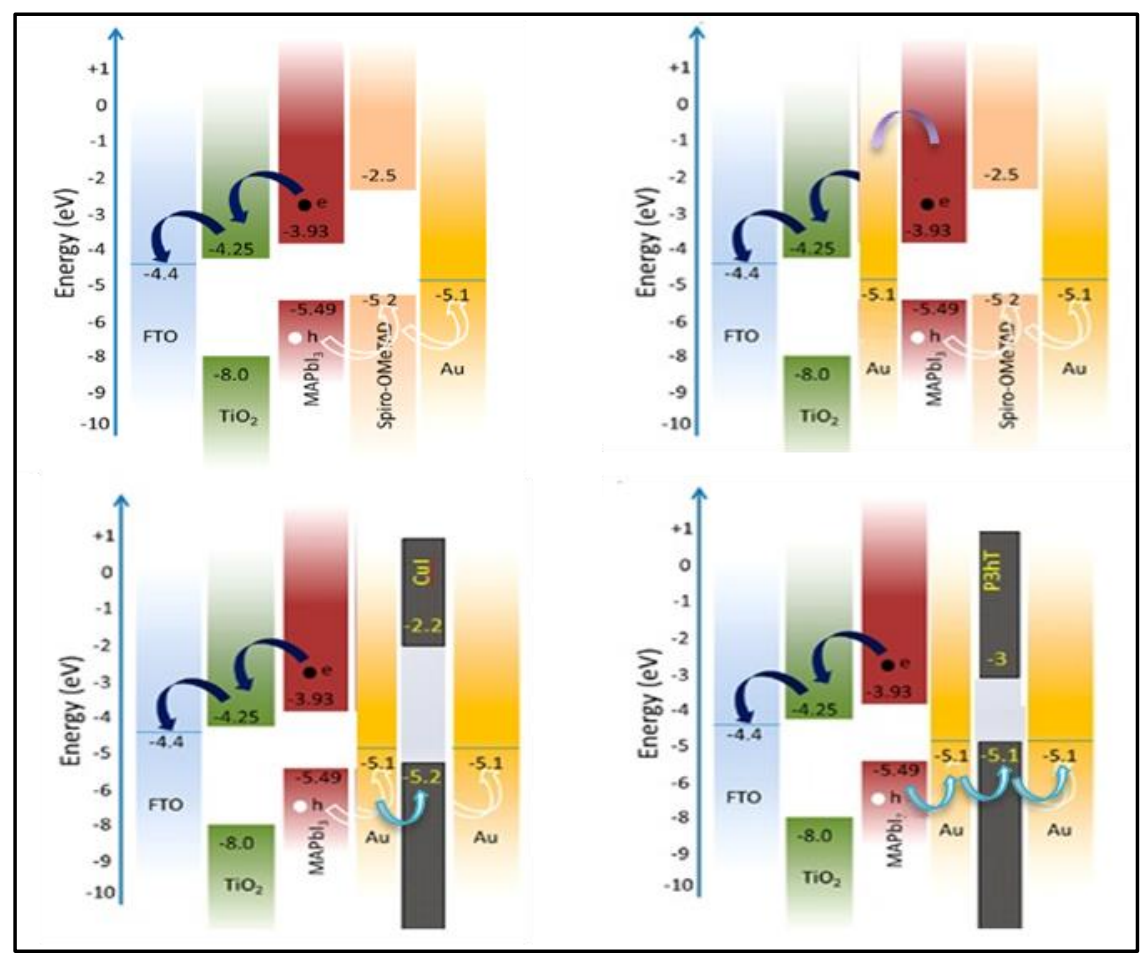

Figure 2: Energy diagram of a typical PSC using $\mathrm{TiO}_{2}$ as the ETM, $\mathrm{MAPbI}_{3}$ as the perovskite absorber, and Spiro-OMeTAD as the HTM. FTO is the front contact, while gold is the back contact [16].

Considering the energy levels shown in Fig. 2, it is obvious that the HOMO energy levels of P3HT, CuI, and spiro are $5.1 \mathrm{eV}, 5.2 \mathrm{eV}$ and $5.1 \mathrm{eV}$, respectively, which are very close. The HOMO for HTL should be higher than HOMO of perovskite layer. Also, it is noted that the Au work function is very close or similar to the HOMO of the prepared HTL. This result shows that the deposition of gold layer between perovskite layer and HTL can be used to improve the solar cells performance because of the work function of gold.

\section{Results and discussion}

The structure of the PSK layers were analyzed with a Shimadzu $6000 \mathrm{X}$-ray diffractometer, using $\mathrm{Cu} \mathrm{K} \alpha$ radiation of wavelength $1.5406 \mathrm{~A}^{\circ}$. The XRD patterns of the samples were recorded at a scanning rate of $0.08333 \mathrm{o} S-1$ in the $2 \Theta$ ranges $\left(5^{\circ}-80^{\circ}\right)$. Fig. 3 shows the XRD patterns of $\mathrm{CH}_{3} \mathrm{NH}_{3} \mathrm{PbI}_{3}$ layer (PSK layers) with and without using chlorobenzene as anti-solving.

The pattern has many peaks at $2 \Theta$ equal to $14.2^{\circ}, 20.17^{\circ}, 23.66^{\circ}, 24.69^{\circ}, 28.63^{\circ}$, $31.01^{\circ}, 32.04^{\circ}, 35.16^{\circ}$, and $38.2^{\circ}$ which corresponds to Miller indices (h k l) of (110), (112), (211), (202), (220), (213), (222), (042), and (213), respectively. The XRD measurements proved that the $\mathrm{MAPbI}_{3}$ layer is of tetragonal structure. It can also be seen that chlorobenzene did not affect the structure of the perovskite layer. 


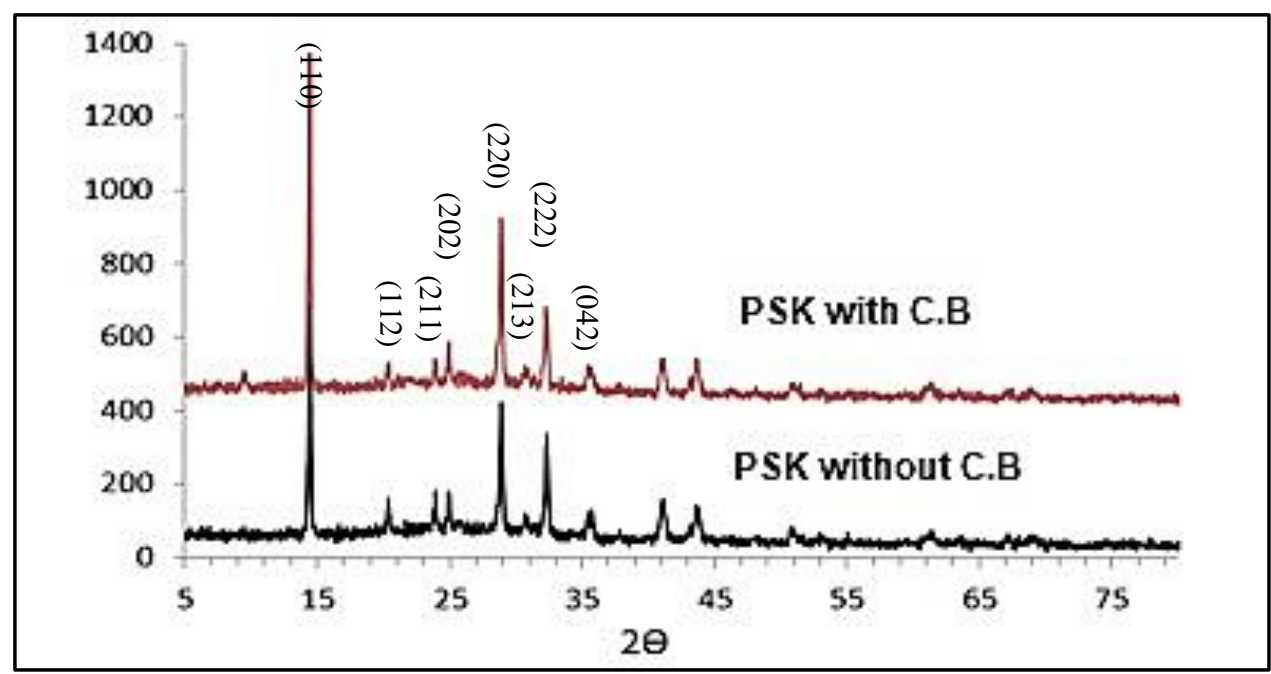

Figure 3: $X$-ray diffraction pattern of the PSK layer with and without using chlorobenzene as anti-solving.

The XRD pattern of gold is shown in Fig. 4. The $2 \Theta$ angles are $38.27^{\circ}, 44.48^{\circ}$, $64.73^{\circ}, 77.76^{\circ}, 81.937^{\circ}, 98.4^{\circ}, 111.17^{\circ}, 115.65^{\circ}$, corresponding to Miller indices (hkl) (111), (200), (202), (311), (222), (400), (313), (202), respectively. The XRD measurements denoted cubic structure space group Fm-3m, $a=4.069 \AA$. The patterns and these results are in agreement with those of Oku [17].

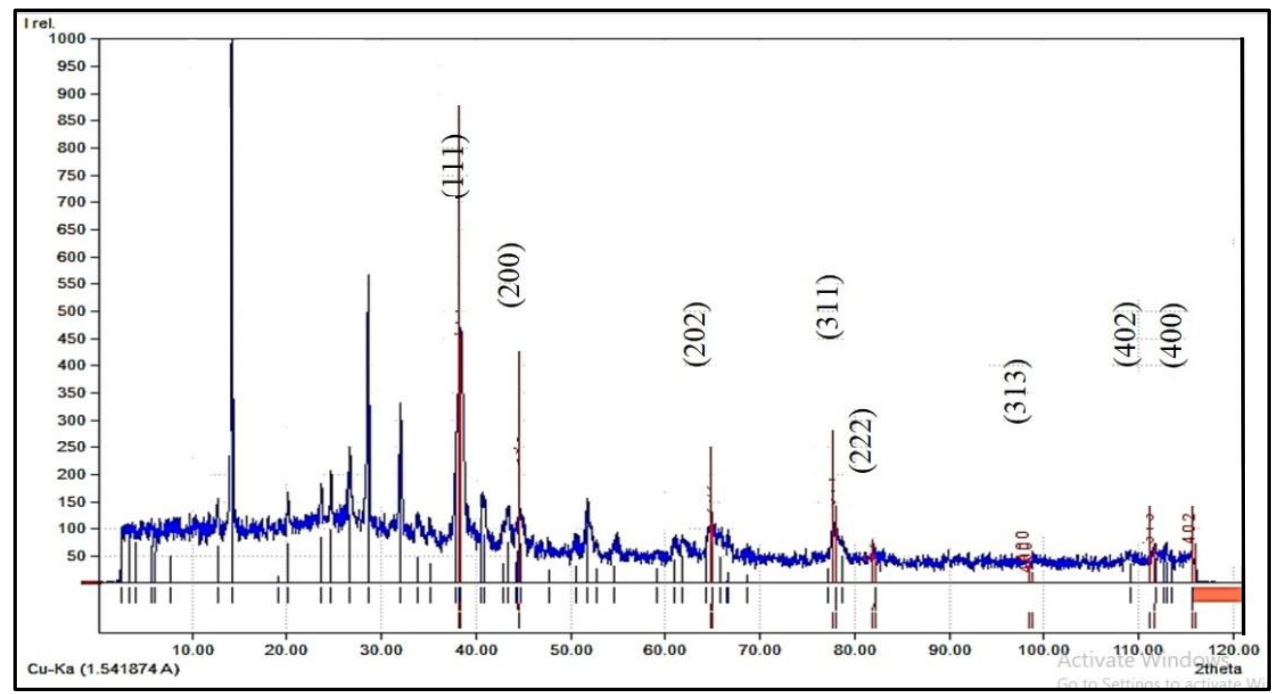

Figure 4: X-ray diffraction pattern of the PSK with gold electrode after one month.

The phase analysis for the X-ray diffractometer data was conducted using Match! Software for phase analysis data Version 3 from Crystal Impact-Software for Chemists and Material Scientists. The software compares the diffraction pattern of samples to a database which containing reference patterns to identify the phases which are present. In XRD Match! Software, there is not any available data for the structure containing Au interacted with the cell layers.

Figure 5 shows the FE-SEM images of perovskite layer prepared with chlorobenzene (Fig.5 a) and without chlorobenzene (Fig. 5 b) anti-solvent in 1 step method. Chlorobenzene was used in the process of preparing perovskite layer for improving the surface properties of the layer. From Fig. 5, it is revealed that using chlorobenzene resulted in a homogeneous layer with good topography. 


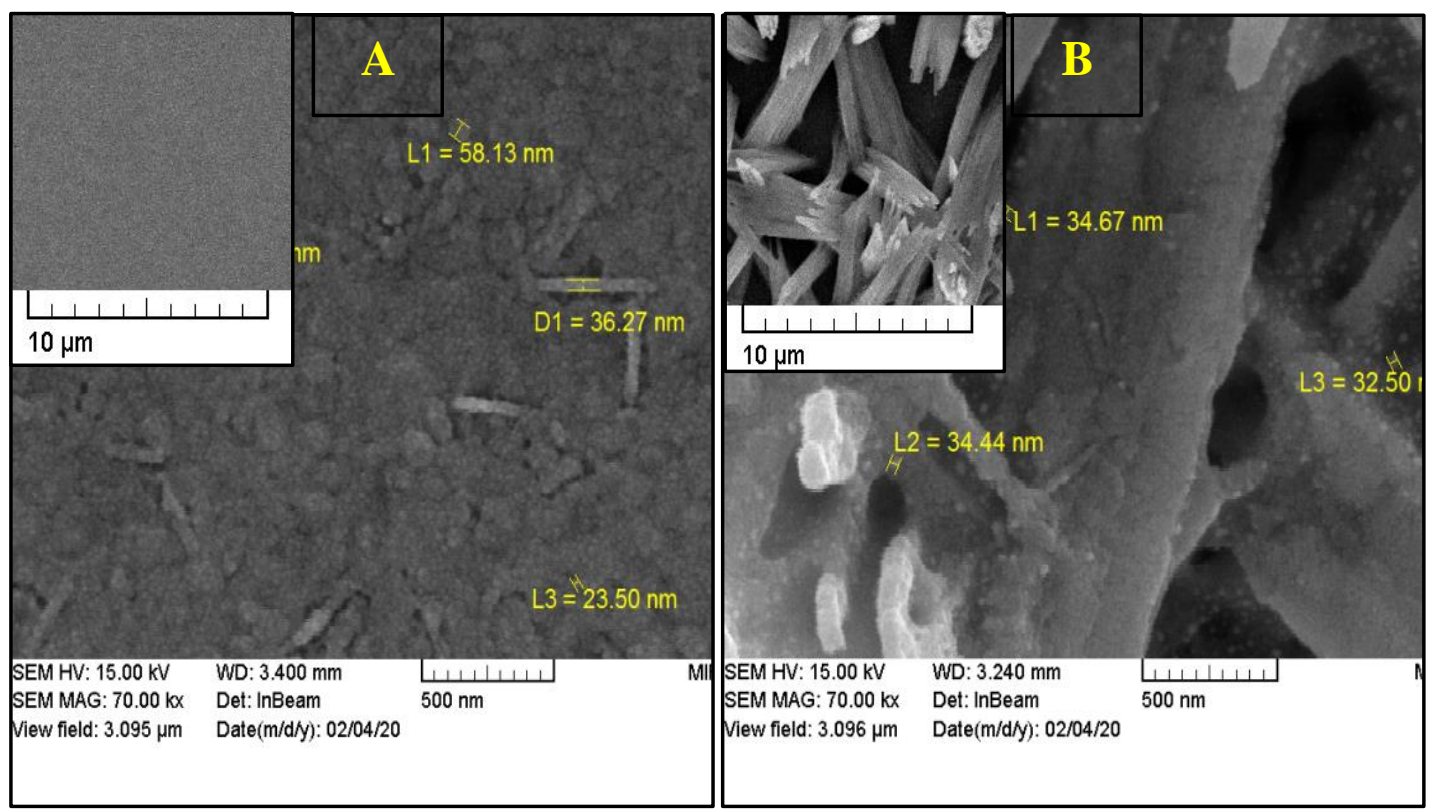

Figure 5: Top-view of FE-SEM images for PSK layer, A: PSK with C.B anti-solvent, B: $P S K$ without C.B anti-solvent. L1, L2 and L3 are the grain sizes and D1 is the rod diameter.

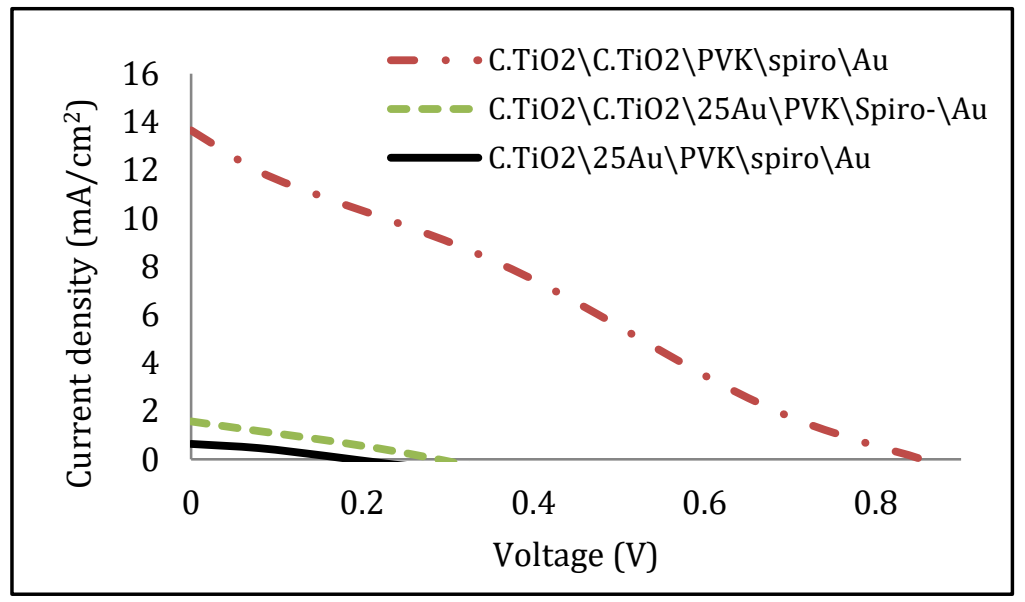

Figure 6: J-V characteristics of PSKs with thin Au layer between ETL and PSK.

Au layer of thickness $25 \mathrm{~nm}$ was deposited between ETL and PSK layer according to the structure in Table (1). The results of J-V characteristics of these structures (Fig. 6) show that the cells performance was reduced after depositing Au layer between ETL and PSK, which refer to the importance of ETL layer in the process of energy transformation in the solar cell.

The presence of the Au layer prevents the contact between ETL and PSK, but it does not cancel the ETL's role. The performance of PSC was also reduced when using one thin layer of ETL, which indicates that the ETL is essential in the functioning of the PSCs. 
Table 1: Perovskite solar cell with thin Au layer between ETL and PSK Parameters.

\begin{tabular}{|c|c|c|c|c|c|c|}
\hline ETL Type & $V_{\text {oc }}(v)$ & $\mathbf{J}_{\mathrm{sc}}(\mathbf{m A})$ & $V_{\max }(\mathbf{V})$ & $I_{\max }(\mathbf{m A})$ & F. F & $\eta \%$ \\
\hline C. $\mathrm{TiO}_{2} \backslash \mathrm{C} . \mathrm{TiO}_{2} \backslash \mathrm{PSK} \mid$ & 0.55 & 13.65 & 0.40 & 7.55 & 0.40 & 3 \\
\hline $\mathrm{TiO}_{2} \backslash \mathrm{C} \cdot \mathrm{TiO}_{2} \backslash 25 \mathrm{Au}$ & 0.3 & 1.57 & 0.32 & 0.34 & 0.22 & 0.11 \\
\hline C. $\mathrm{TiO}_{2} \backslash 25 \mathrm{Au} \backslash \mathrm{PSK} \backslash$ spiro $\backslash \mathrm{Au}$ & 0.24 & 0.64 & 0.32 & 0.14 & 0.29 & 0.08 \\
\hline
\end{tabular}

A thin Au layer of thickness $25 \mathrm{~nm}$ was deposited between PSK layer and HTL. Two types of HTL were used: CuI and P3HT. Fig. 7 and Table (2) summarize the cell parameters measurements. It is clear that the efficiency of the cell with P3HT was lower than that with Spiro-OMeTAD. When Au layer was deposited between P3HT and PSK layer, the efficiency increased from 1 to 2.6 , which is close to the efficiency with SpiroOMeTAD. Also, $\mathrm{I}_{\mathrm{sc}}$ was increased from $10.7 \mathrm{~mA}$ to $30.5 \mathrm{~mA}$, but $\mathrm{V}_{\text {oc }}$ was decreased from $0.7 \mathrm{~V}$ to $0.5 \mathrm{~V}$.

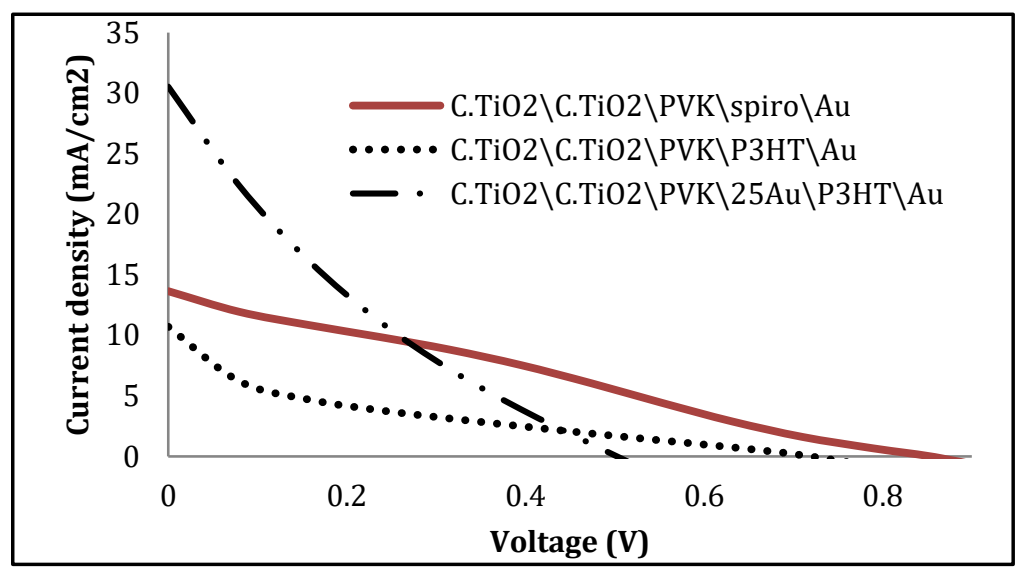

Figure 7: J-V characteristics of PSKs with thin Au layer between P3HT HTL and PSK.

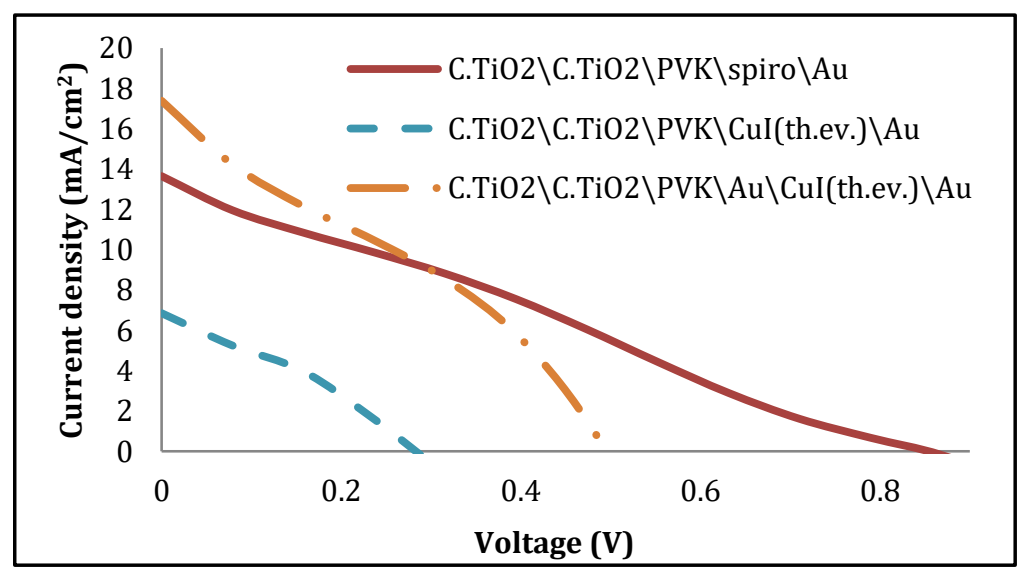

Figure 8: J-V characteristics of PSKs with thin Au layer between CuI as HTL and PSK.

Also, $\mathrm{CuI}$ was deposited, using thermal evaporation method, as the HTL and Au layer was deposited between $\mathrm{CuI}$ and PSK layers. The J-V characteristics of PSC with CuI HTL are shown in Fig. 8 and Table (2) where the efficiency has increased from $0.5 \%$ to $2.7 \%$ when $25 \mathrm{~nm} \mathrm{Au}$ layer was deposited between PSK and CuI layer. It approaches the efficiency of PSC with Spiro-OMeTAD as the HTL. Furthermore, the $\mathrm{I}_{\mathrm{sc}}$ increased from $6.8 \mathrm{~mA}$ to $17.4 \mathrm{~mA}$ and $\mathrm{V}_{\mathrm{oc}}$ from $0.3 \mathrm{~V}$ to $0.5 \mathrm{~V}$. 
Table 2: Perovskite solar cell parameters measured with thin Au layer between HTL and PSK.

\begin{tabular}{|c|c|c|c|c|c|c|}
\hline ETL Type & $\mathbf{V}_{\text {oc }}(\mathbf{v})$ & $\mathbf{J}_{\mathrm{sc}}(\mathbf{m A})$ & $\mathbf{V}_{\max }(\mathbf{V})$ & $I_{\max }(\mathbf{m A})$ & F. F & $\eta \%$ \\
\hline$\overline{\mathrm{C} . \mathrm{TiO}_{2} \backslash \mathrm{C} . \mathrm{TiO}_{2} \backslash \mathrm{PSK} \backslash \text { spiro } \backslash \mathrm{Au}}$ & 0.55 & 13.65 & 0.40 & 7.55 & 0.40 & 3 \\
\hline C. $\mathrm{TiO}_{2} \backslash \mathrm{C} . \mathrm{TiO}_{2} \backslash \mathrm{PSK} \backslash \mathrm{CuI}($ th.ev. $) \backslash \mathrm{Au}$ & 0.30 & 6.85 & 0.32 & 1.59 & 0.23 & 0.50 \\
\hline $\mathrm{C} . \mathrm{TiO}_{2} \backslash \mathrm{C} . \mathrm{TiO}_{2} \backslash \mathrm{PSK} \backslash \mathrm{Au} \backslash \mathrm{CuI}($ th. $) \backslash \mathrm{Au}$ & 0.50 & 17.39 & 0.32 & 8.55 & 0.28 & 2.70 \\
\hline 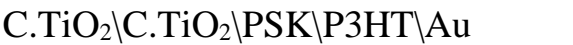 & 0.75 & 10.71 & 0.32 & 3.13 & 0.12 & 0.99 \\
\hline $\mathrm{C} . \mathrm{TiO}_{2} \backslash \mathrm{C} . \mathrm{TiO}_{2} \backslash \mathrm{PSK} \backslash 25 \mathrm{Au} \backslash \mathrm{P} 3 \mathrm{HT} \backslash \mathrm{Au}$ & 0.50 & 30.54 & 0.24 & 11.14 & 0.16 & 2.64 \\
\hline
\end{tabular}

From the results, one can conclude that depositing Au layer between the perovskite layer and ETL led to a significantly reduction in the efficiency of the solar cell. This refers that ETL has an essential role because Au layer prevents the direct contact between perovskite and ETL. This will increase the recombination and reduce visible light that is absorbed in the process of separating the electron-hole, which is formed in the PSK layer by the process of converting light energy.

On the other hand, using P3HT and CuI as HTL in PSC and depositing Au layer between the perovskite layer and the HTL has good effect on the cell efficiency, where the efficiency of the cell was improved by about 2.5 times (as concluded from the results of Fig. 7 and 8 and Table (2)). This indicates that the HTL may interact with the perovskite layer, but the gold layer prevented this interaction as well as improving the holes transfer process to the HTL.

\section{Conclusions}

A solar cell has been successfully fabricated with acceptable performance. To the best of our knowledge, this is the first time Au layer was added between the perovskite layer and the HTL and between the perovskite layer and the ETL. Inserting an Au layer between the perovskite layer and the HTL improved the efficiency of the cell by about 2.5 times more than the cell without Au layer. However, using P3HT and CuI as HTLs with an $\mathrm{Au}$ between ETL and perovskite layer reduced the efficiency. The ETL is essential in the function of the PSCs.

\section{Acknowledgments}

The authors would like to thank Photonics of the Physics department in the Colleges of Science, University of Baghdad for their valuable support and to provide the necessary facilities for research. Thanks, extended to the Organic Materials and Polymers (POMP) Laboratory in Shahid Beheshti University, Laser and Plasma Research Institute (LAPRI), for allowing us to use the preparation and examination devices available in Laboratory.

\section{Conflict of interest}

Authors declare that they have no conflict of interest.

\section{References}

1. Yu Z. and Sun L., Recent progress on hole-transporting materials for emerging organometal halide perovskite solar cells. Advanced Energy Materials, 2015. 5(12): pp. 1500213.

2. Yusoff A.R.b.M. and Nazeeruddin M.K., Organohalide lead perovskites for photovoltaic applications. The journal of physical chemistry letters, 2016. 7(5): pp. 851-866. 
3. Chaudhary D.K., Kumar P., and Kumar L., Realization of efficient perovskite solar cells with MEH: PPV hole transport layer. Journal of Materials Science: Materials in Electronics, 2017. 28(4): pp. 3451-3457.

4. Kodeary A., Hamidi S., and Moradlou R., Voltage controlled properties of piezomagneto-plasmonic core/shell nanoparticles. Nano-Structures and Nano-Objects, 2020. 21: pp. 100415.

5. Saliba M., Matsui T., Seo J.-Y., Domanski K., Correa-Baena J.-P., Nazeeruddin M.K., Zakeeruddin S.M., Tress W., Abate A., and Hagfeldt A., Cesium-containing triple cation perovskite solar cells: improved stability, reproducibility and high efficiency. Energy environmental science, 2016. 9(6): pp. 1989-1997.

6. Wang Q., Phung N., Di Girolamo D., Vivo P., and Abate A., Enhancement in lifespan of halide perovskite solar cells. Energy Environmental Science, 2019. 12(3): pp. 865886.

7. Jeong J., Kim M., Seo J., Lu H., Ahlawat P., Mishra A., Yang Y., Hope M.A., Eickemeyer F.T., Kim M., et al., Pseudo-halide anion engineering for $\alpha$-FAPbI 3 perovskite solar cells. Nature, 2021. 592(7854): pp. 381-385.

8. Ng A., Ren Z., Shen Q., Cheung S.H., Gokkaya H.C., So S.K., Djurišić A.B., Wan Y., Wu X., and Surya C., Crystal engineering for low defect density and high efficiency hybrid chemical vapor deposition grown perovskite solar cells. ACS applied materials interfaces, 2016. 48(8): pp. 32805-32814.

9. Roy P., Sinha N.K., Tiwari S., and Khare A ,.A review on perovskite solar cells: Evolution of architecture, fabrication techniques, commercialization issues and status. Solar Energy, 2020. 198: pp. 665-688.

10. You J., Meng L., Song T.-B., Guo T.-F., Yang Y.M., Chang W.-H., Hong Z., Chen $\mathrm{H}$., Zhou H , and Chen Q., Improved air stability of perovskite solar cells via solutionprocessed metal oxide transport layers. Nature nanotechnology, 2016. 11(1): pp. 7581.

11. Zhang P., Wu J., Zhang T., Wang Y., Liu D., Chen H., Ji L., Liu C., Ahmad W., and Chen Z.D., Perovskite solar cells with $\mathrm{ZnO}$ electron-transporting materials. Advanced Materials, 2018. 30(3): pp. 1703737.

12. Faß1 P., Exploration of Properties, Stability and Reproducibility of Perovskite Solar Cells, Ph. D. Thesis, RUPERTO-CAROLA UNIVERSITY OF HEIDELBERG, GERMANY, 2019.

13. Im J.-H., Lee C.-R., Lee J.-W., Park S.-W., and Park N.-G., 6.5\% efficient perovskite quantum-dot-sensitized solar cell. Nanoscale, 2011. 3(10): pp. 4088-4093.

14. Assi A.A., Saleh W.R., and Mohajerani E. Effect of Metals (Au, Ag, and Ni) as Cathode Electrode on Perovskite Solar Cells. in IOP Conference Series: Earth and Environmental Science. 2021. IOP Publishing. No. 1, 012019, pp. 1-8.

15. Assi A.A., Saleh W.R., and Mohajerani E. Investigate of $\mathrm{TiO}_{2}$ and $\mathrm{SnO}_{2}$ as electron transport layer for perovskite solar cells. in AIP Conference Proceedings. 2020 .AIP Publishing LLC. No. 1, 050039, pp. 1-9.

16. Jena A.K., Kulkarni A., and Miyasaka T., Halide perovskite photovoltaics: background, status, and future prospects. Chemical reviews, 2019. 119(5): pp. 30363103.

17. Oku T., Crystal structures of $\mathrm{CH} 3 \mathrm{NH} 3 \mathrm{PbI} 3$ and related perovskite compounds used for solar cells. Solar Cells-New Approaches Reviews, 2015. 1. ed.1, IntechOpen. 


\title{
تأثير ترسيب طبقة رقيقة من الذهب بين طبقات خلية بيروفسكايت الثمسية على أداء الخلية التهن طنية
}

\author{
احمد علي عاصي1 و وسن رشيد صالح² و عز الدين مهاجراني3

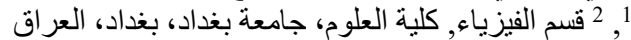

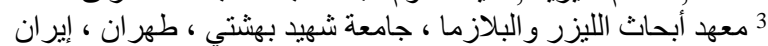

الخلاصة

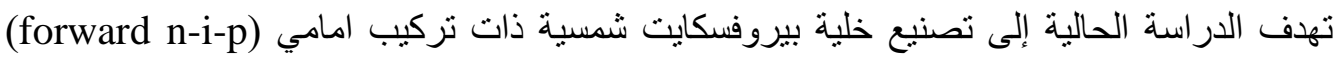

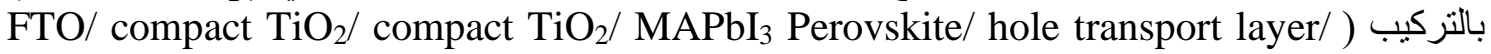

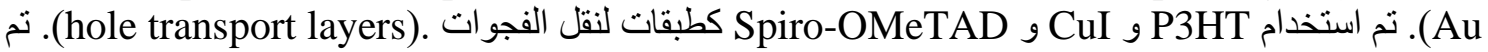
ترسيب طبقة رقيقة 25 نانومتر من الذهب بين طبقة نقل الإلكترونات وطبقة البيروفسكايت ومن ثم ترسيب طبقة

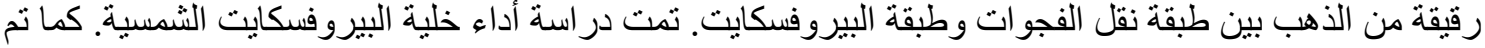

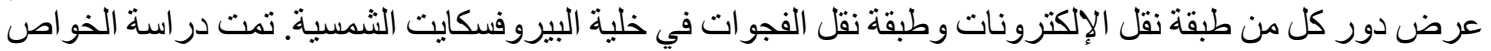

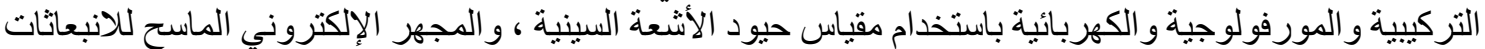

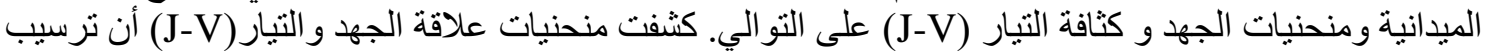

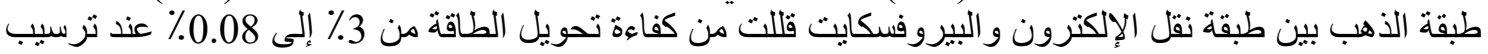

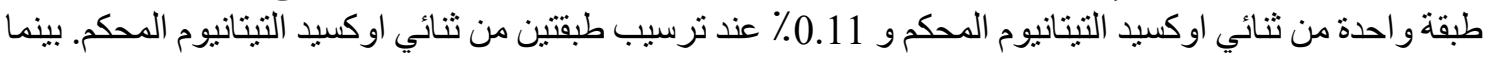

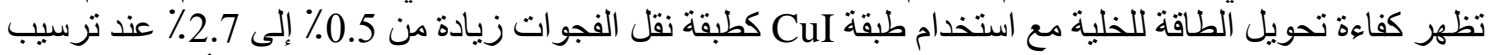

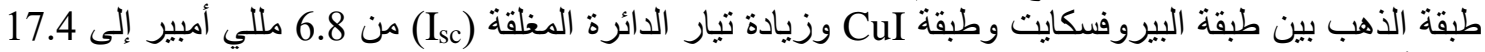

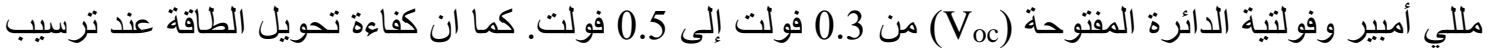

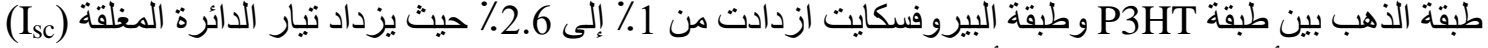
من 10.7 مللي أمبير إلى 30.5 مللي أمبير لكن فولتية الدائرة المفتوحة تنخفض من 0.7 فولت الت إلى 0.5 فولت. 